\title{
Numerical Modelling of a Concentrating Photovoltaic Thermal Collector
}

\author{
M. Valizadeh, F. Sarhaddi*and F. Sobhnamayan \\ Research Laboratory of Renewable Energies and Electromagnetic Fluids, \\ Department of Mechanical Engineering, University of Sistan and Baluchestan, \\ Zahedan, Iran \\ Phone: +98 54 31136465; Fax: +98 5433447092 \\ *E-mail: fsarhaddi@eng.usb.ac.ir
}

\begin{abstract}
In this paper, the performance evaluation of a concentrating photovoltaic thermal (CPVT) collector is carried out. By writing energy, balance for the various components of CPVT collector, a set of nonlinear equations is obtained to calculate the temperature of different parts of the system. The electrical parameters of the CPVT collector are calculated by the four-parameter model of current-voltage. The simulation results of the present study are in good accordance with the previous studies data. The results show that with the fluid velocity increase from 0.08 to $0.43 \mathrm{~m} / \mathrm{s}$, the electrical efficiency and thermal efficiency increase by $1.05 \%$ and $2.2 \%$, respectively. The thermal efficiency is enhanced by $9.4 \%$ as the receiver width is increased from 0.06 to $0.2 \mathrm{~m}$. With the increase of diameter pipe from 0.017 to $0.06 \mathrm{~m}$ an increase of $2.75 \%$ and $3.9 \%$ is observed in the thermal and electrical efficiencies, respectively. The thermal efficiency has an ascending/descending trend with the increase of collector length. The increase of fluid inlet temperature from 273.15 to $363.15 \mathrm{~K}$ reduces the thermal and electrical efficiencies by $7.3 \%$ and $4.05 \%$, respectively. The increase of the incident beam radiation from 300 to $1000 \mathrm{~W} / \mathrm{m}^{2}$ enhances the electrical efficiency by $4 \%$, while the thermal efficiency has an ascending/descending trend. The ambient temperature increase causes an increase of $5.1 \%$ in thermal efficiency. The effect of receiver width and ambient temperature on electrical efficiency is negligible.
\end{abstract}

Keywords: Concentrating photovoltaic thermal (CPVT) collector; numerical modelling; thermal efficiency; electrical efficiency.

\section{NOMENCLATURE}

\begin{tabular}{|c|c|c|c|}
\hline a & ideality factor & \multicolumn{2}{|c|}{ Subscripts } \\
\hline A & $\operatorname{area}\left(\mathrm{m}^{2}\right)$ & $\mathrm{a}$ & ambient \\
\hline $\mathrm{C}_{\mathrm{f}}$ & $\begin{array}{l}\text { fluid specific heat capacity }(\mathrm{J} / \mathrm{kg} \\
\mathrm{K})\end{array}$ & ap & aperture \\
\hline $\mathrm{C}_{\mathrm{pvt}}$ & concentration ratio & $\mathrm{b}$ & beam \\
\hline $\mathrm{D}$ & fluid channel diameter $(\mathrm{m})$ & back & back surface \\
\hline $\mathrm{f}$ & Darcy friction coefficient & $\mathrm{c}$ & channel \\
\hline G & radiation $\left(\mathrm{W} / \mathrm{m}^{2}\right)$ & conc & concentrator \\
\hline $\mathrm{h}_{\text {conv }}$ & $\begin{array}{l}\text { convective heat transfer } \\
\text { coefficient }\left(\mathrm{W} / \mathrm{m}^{2} \mathrm{~K}\right)\end{array}$ & el & electrical \\
\hline $\mathrm{h}_{\mathrm{f}}$ & $\begin{array}{l}\text { fluid heat transfer coefficient } \\
\left(\mathrm{W} / \mathrm{m}^{2} \mathrm{~K}\right)\end{array}$ & en & energy \\
\hline
\end{tabular}




\begin{tabular}{|c|c|c|c|}
\hline 1 & circuit current (A) & $\mathrm{f}$ & fluid \\
\hline $\mathrm{I}_{\mathrm{L}}$ & current light (A) & hex & lateral area of the fluid channel \\
\hline $\mathrm{L}$ & length (m) & in & inlet \\
\hline$\dot{\mathrm{m}}$ & mass flow rate $(\mathrm{kg} / \mathrm{s})$ & $\mathrm{L}_{\mathrm{pvt}, \mathrm{i}}$ & ith PVT Length \\
\hline $\mathrm{N}$ & Number of cells & $\mathrm{mp}$ & maximum power point \\
\hline $\mathrm{p}$ & Pressure $(\mathrm{Pa})$ & net & net \\
\hline $\mathrm{P}$ & Power (W) & oc & open-circuit \\
\hline$r$ & $\begin{array}{l}\text { Area specific thermal resistance } \\
\left(\mathrm{m}^{2} \mathrm{~K} / \mathrm{W}\right)\end{array}$ & opt & optical \\
\hline $\mathrm{R}_{\mathrm{s}}$ & Series resistance $(\Omega)$ & out & outlet \\
\hline $\mathrm{Re}$ & Reynolds Number & $\begin{array}{l}\text { present } \\
\text { study }\end{array}$ & present study \\
\hline $\mathrm{T}$ & Temperature (K) & pump & pump \\
\hline V & Circuit voltage (V) & $\mathrm{pv}$ & photovoltaic \\
\hline$\underline{V}_{f}$ & Fluid velocity $(\mathrm{m} / \mathrm{s})$ & pvt & photovoltaic/thermal collector \\
\hline$\overline{\mathrm{V}}_{\mathrm{f}}$ & Average velocity of fluid $(\mathrm{m} / \mathrm{s})$ & rec & receiver \\
\hline $\mathrm{w}_{\mathrm{a}}$ & Wind velocity $(\mathrm{m} / \mathrm{s})$ & ref & reference \\
\hline \multicolumn{2}{|c|}{ Greek symbols } & sc & short-circuit \\
\hline$\alpha$ & $\begin{array}{l}\text { absorptivity coefficient, current } \\
\text { temperature coefficient }\left(\mathrm{mA} /{ }^{\circ} \mathrm{C}\right)\end{array}$ & $\operatorname{sim}$ & present study simulated \\
\hline$\beta$ & $\begin{array}{l}\text { temperature coefficient of } \\
\text { voltage }\left(\mathrm{V} /{ }^{\circ} \mathrm{C}\right)\end{array}$ & sky & sky \\
\hline$\varepsilon$ & emissivity & sub & substrate \\
\hline$\varepsilon_{h}$ & heat exchanger effectiveness & th & thermal \\
\hline$\varepsilon$ & $\begin{array}{l}\text { semiconductor band gap energy } \\
(\mathrm{eV})\end{array}$ & top & top surface of receiver \\
\hline$\eta$ & efficiency & & \\
\hline$\rho$ & density $\left(\mathrm{kg} / \mathrm{m}^{3}\right)$, refelectivity & & \\
\hline$\sigma$ & $\begin{array}{l}\text { Stephan-Boltzmann constant } \\
\left(\mathrm{W} / \mathrm{m}^{2} \mathrm{~K}^{4}\right)\end{array}$ & & \\
\hline
\end{tabular}

\section{INTRODUCTION}

Renewable energies in the coming years will replace fossil fuels for clean and renewable nature. Solar energy is one of the most important renewable energy sources. Major applications of solar energy can be categorised into two categories: solar thermal collector, which converts solar energy into thermal energy, and photovoltaic (PV) module, which converts solar energy into electrical energy. Usually, the application of solar collector ad PV module is separate. In the solar collector, an external electrical source is needed to circulate the agent fluid through the collector system.

On the other hand, in the PV module, the module electrical efficiency decreases sharply as the temperature of the PV module increases. Therefore, in order to obtain higher electrical efficiency, the PV module should be cooled. In order to eliminate an external electrical source and to cool the PV module, the PV module is integrated with the solar thermal collector. Such a system is called a photovoltaic thermal (PVT) collector. The PVT collector produces thermal and electrical energy simultaneously. Although the initial idea of PVT collectors was developed about 45 years ago, this product is still not economically feasible, and many researchers are investigating new designs [1]. One of the schemes under consideration is the concentrating photovoltaic thermal 
collector (CPVT), which is formed by placing PVT collectors in the focal point of some reflectors to increase the solar flux on the PV module. Due to the use of a smaller number of PV cells per unit area, the cost of this system is considerably less than that of the flat plate PVT collector. Given their capacity for generating more heat and power than PVTs, CPVTs have become very popular for both domestic and industrial applications.

Sharaf and Orhan $[2,3]$ provided a comprehensive review of the scientific basis and technologies used in CPVT systems in two parts. The first part [2] includes the specifications and considerations of the CPVTs design to review the principles and technologies behind the CPVTs. The second part [3] reviews the published articles, applications and the performance evaluation of CPVTs. Considering the importance of CPVTs and their new technology, Azarian et al. [4] have conducted a comprehensive thematic review on CPVTs. In their article, the thermal and electrical performance was described analytically, numerically and experimentally through explaining the details of the systems and how the CPVTs are evaluated. In the conclusion of their study, they argued that CPVTs have a high potential to compete with pre-existing commercial systems in the near future.

In references of [2-4], a literature survey about CPVTs from a variety of perspectives have been presented. However, few theoretical or experimental studies have addressed the performance of CPVT systems in comparison with conventional solar systems. Bernardo et al. constructed and studied the performance of a parabolic trough PVT collector, experimentally. Their CPVT system consists of a linear parabolic concentrator and a single-axis collector with a triangular cross-section that is installed at the focal point of the concentrator. The concentrator aperture area is covered with a glass cover. The two sides of the surface of the receiver that face the parabolic concentrator are covered by PV cells. However, it should be noted that the width of the module is less than the width of the triangular receiver, so the receiver absorbs solar radiation from the concentrator, as well. Its upper (top) surface also directly absorbs the solar radiation. Inside the triangular receiver, a channel with a circular cross-section is located through which the agent fluid flows. Calise and Vanoli [6] conducted a thermal analysis on the CPVT of Bernardo et al. [5] by applying two changes; they removed the glass cover from the aperture area and used triple junction cells instead of monocrystalline silicon cells. They concluded that system performance is very good even when the fluid temperature is high. The schematic view of CPVT system and its receiver are shown in Figures 1 and 2 , respectively.

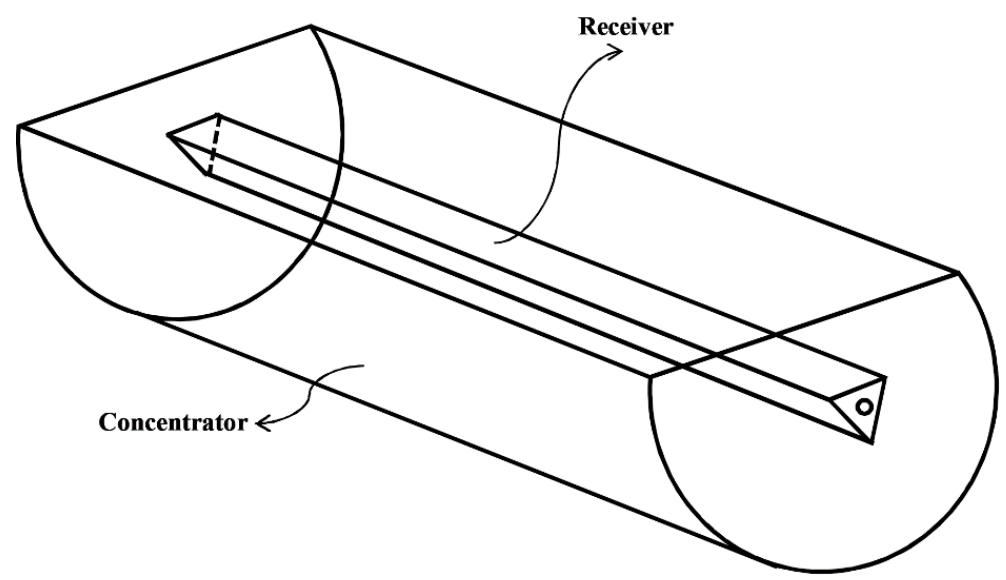

Figure 1. The schematic view of CPVT system in the present study 


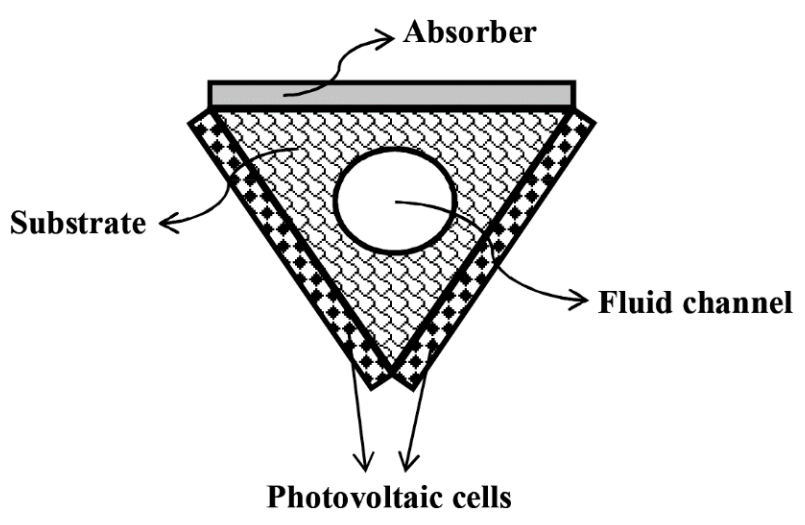

Figure 2. The schematic view of the receiver in the present study.

Calise et al. [7] have also modelled the CPVT system by the finite volume technique. Their model was able to calculate the temperature of the system at different points along the system axis. Also, they calculated irreversibility rates and the exergy efficiency of the CPVT system. Mohsenzadeh et al. [8] constructed a system similar to that of Bernardo et al. [5] and Calise and Vanoli [6]. In order to generate more electricity than the heat from solar cells, they used thermoelectric modules in a triangular receiver, between the coolant channel and the PV cells. Their measurements showed that the average daily electrical efficiency and thermal efficiencies are $4.83 \%$ and $46.16 \%$, respectively. Sharaf and Orhan [9] designed and analysed a densely packed CPVT collector. Their design includes parabolic dish concentrators, multi-junction photovoltaic cells, segmented thermoelectric generator couples with interconnectors, and finned mini channel heat extractors. They investigated the configuration of series and parallel of receiver for the proposed CPVT collector. Their results showed that the parallel configuration provides both a meaningful electrical output as well as relatively highquality thermal output. Thus, it is suitable for applications with high temperature as well as electricity. Karathanassis et al. [10] developed a dynamic, theoretical model suitable for the prediction of the long-term performance of a CPVT system. Their model was able to predict the daily performance of CPVT system for different values of the cooling fluid flow rate and temperature under various environmental conditions. Also, they calculated the exergy efficiency of the CPVT system. They concluded that the exergy efficiency is a direct function of the electrical efficiency and the optical quality of the parabolic dish. Their results showed that an increase of $12-24 \%$ could be seen in the exergy efficiency for the electrical efficiency of $25 \%$ and the optical quality of $75 \%$.

In order to calculate the electrical efficiency of the photovoltaic module, an empirical equation is used in the previous studies [1-10]. This empirical equation has some deficiencies. It cannot be used if the geometry of the CPVT system changes. On the other hand, it does not include the details of changes in electrical parameters such as opencircuit voltage, short-circuit current, voltage and current at the maximum power point, and other electrical parameters. It also has a significance error in low solar radiation intensity. In low solar radiation intensity, the electrical efficiency should be tend to a low value. However, the empirical equation gives the electrical efficiency equivalent to the electrical efficiency of the reference conditions. In this paper, a numerical approach is employed to carry out a comprehensive energy analysis for the CPVT system provided by Calise and Vanoli [6]. Because there is an electrical efficiency in the energy balance equations, the thermal analysis depends on the electrical analysis. In this study, a comprehensive electrical analysis is performed based on a four-parameter electrical 
model of current-voltage. Therefore, by correcting the electrical model and taking into account the fluid pressure loss and the pump power consumption, the thermal and electrical efficiencies are calculated.

\section{METHODS AND MATERIALS}

In order to obtain the governing equations of the thermal modelling of the CPVT system, the energy balance is developed on the various components of the CPVT system of Calise and Vanoli [6]. The assumptions of the thermal modelling are as follows [6]:

i. The processes are quasi-steady.

ii. The kinetic and gravitational terms in the energy balance may be ignored.

iii. The solar radiation is focused evenly along the module surface.

iv. Water is the coolant agent fluid.

v. The flow in the channel is fully developed.

vi. The temperature gradient along with the thickness of the photovoltaic module and in the metal substrate can be ignored.

vii. The photovoltaic modules, absorber, and concentrators are diffuse-gray surfaces. The temperature gradient in the photovoltaic module is negligible due to its low thickness, and in the metal substrate due to its high conductivity. Therefore, the temperature is uniform in the photovoltaic module and the metal substrate.

Five control volumes are used to obtain the temperature of the different components of the CPVT system. The first energy balance is written for a control volume that includes the entire triangular receiver [6]:

$$
\begin{aligned}
& \mathrm{A}_{\text {pvt }} \mathrm{G}_{\mathrm{b}} \mathrm{C}_{\text {pvt }}+\mathrm{A}_{\text {top }} \mathrm{G}_{\text {top }} \alpha_{\text {top }}=\dot{\mathrm{m}} \mathrm{C}_{\mathrm{f}}\left(\mathrm{T}_{\mathrm{f} \text {, out }}{ }^{-}\right. \\
& \left.\mathrm{T}_{\mathrm{f}, \text { in }}\right)+\mathrm{A}_{\mathrm{pvt}} \mathrm{G}_{\mathrm{b}} \mathrm{C}_{\mathrm{pvt}} \eta_{\text {opt }} \eta_{\mathrm{pv}}+\mathrm{A}_{\mathrm{pvt}} \mathrm{G}_{\mathrm{b}} \mathrm{C}_{\mathrm{pvt}} \eta_{\text {opt }} \rho_{\text {pvt }}+\mathrm{A}_{\text {top }} \sigma \varepsilon_{\text {top }}\left(\mathrm{T}_{\text {top }}^{4}\right. \\
& \left.\mathrm{T}_{\text {sky }}^{4}\right)+\mathrm{A}_{\text {pvt }} \sigma \varepsilon_{\text {pvt }}\left(\mathrm{T}_{\text {pvt }}^{4}-\mathrm{T}_{\text {conc }}^{4}\right)+\mathrm{A}_{\text {pvt }} \mathrm{h}_{\text {conv, pvt }}\left(\mathrm{T}_{\text {pvt }}-\mathrm{T}_{\mathrm{a}}\right)+\mathrm{A}_{\text {top }} \mathrm{h}_{\text {conv, top }}\left(\mathrm{T}_{\text {top }}-\mathrm{T}_{\mathrm{a}}\right)
\end{aligned}
$$

where $T_{\text {pvt }}, T_{\text {top }}, T_{\text {conc }}, T_{\text {f,out }}, T_{\text {f,in }}, T_{\text {sky }}, T_{a}, A_{\text {pvt }}, A_{\text {top }}, A_{\text {ap }}, \dot{m}, \alpha_{\text {top }}, \varepsilon_{\text {top }}, \varepsilon_{\text {pvt }}, \rho_{\text {pvt }}, \eta_{\text {opt }}, \sigma$, $\mathrm{h}_{\text {conv,pvt }}, \mathrm{h}_{\text {conv, top }}$ and $\mathrm{C}_{\mathrm{f}}$ are the PVT surface temperature, top surface temperature of the receiver (absorber), concentrator surface temperature, fluid outlet temperature, fluid inlet temperature, the sky temperature, ambient temperature, the area of PV cells, the top surface area of receiver, the aperture area, mass flow rate of water, absorptivity of top surface, emissivity of top surface, emissivity of PV cells, reflectivity of PV cells, optical efficiency of concentrator, the Stephan-Boltzmann constant, convective heat transfer coefficient from PV cells to ambient, convective heat transfer coefficient from top surface to ambient and specific heat capacity of water, respectively. Also, the parameter of $\mathrm{C}_{\mathrm{pvt}}=\mathrm{A}_{\mathrm{pvt}} / \mathrm{A}_{\mathrm{ap}}$ is concentrating factor a of CPVT system. In general, PV cells absorb only the beam incident radiation $\left(\mathrm{G}_{\mathrm{b}}\right)$. On the other hand, the top surface of receiver absorbs both beam and diffuse radiation $\left(\mathrm{G}_{\text {top }}\right)[6]$.

The second control volume includes the metallic substrate and the fluid channel. In this study, the related control volume can be considered as a heat exchanger. This assumption is acceptable due to the high thermal conductivity of the metallic substrate [6]. The energy balance for the second control volume of the heat exchanger is as follows [6]:

$$
\dot{\mathrm{m} C} \mathrm{f}_{\mathrm{f}}\left(\mathrm{T}_{\mathrm{f}, \text { out }}-\mathrm{T}_{\mathrm{f}, \text { in }}\right)=\varepsilon_{\mathrm{h}} \dot{\mathrm{m}} \mathrm{C}_{\mathrm{f}}\left(\mathrm{T}_{\text {sub }}-\mathrm{T}_{\mathrm{f}, \text { in }}\right)
$$


where $\mathrm{T}_{\text {sub }}$ is the substrate temperature. Also, the parameter of $\varepsilon_{\mathrm{h}}$ is the effectiveness of heat exchanger [11].

$$
\varepsilon_{\mathrm{h}}=1-\mathrm{e}^{-\mathrm{NTU}}
$$

The well-known NTU number can be calculated as follows [11]:

$$
\mathrm{NTU}=\frac{\frac{\mathrm{A}_{\mathrm{hex}}}{\mathrm{h}_{\mathrm{f}}^{-1}+\mathrm{r}_{\mathrm{sub}}}}{\dot{\mathrm{m} \mathrm{C}_{\mathrm{f}}}}
$$

where $r_{\text {sub }}, A_{\text {hex }}$ and $h_{f}$ are the thermal resistance of the metallic substrate, heat exchanger area and the fluid heat transfer coefficient, respectively. The third control volume includes the PVT layer and the metallic substrate. The energy balance for this control volume as follows [6]:

$$
A_{p v t} \frac{T_{p v t}-T_{\text {sub }}}{r_{\text {pvt }, \text { sub }}}=\dot{m} C_{f}\left(T_{f, \text { out }}-T_{f, \text { in }}\right)+A_{\text {top }} \frac{T_{\text {sub }}-T_{\text {top }}}{r_{\text {top }}}
$$

where $r_{\text {pvt,sub }}$ and $r_{\text {top }}$ are the thermal resistance of the PVT layer and the thermal resistance of both the metallic substrate and top absorber surface, respectively. The fourth energy balance equation is considered with respect to the control volume that includes the top surface of the metallic substrate and the top surface of the triangular receiver [6]:

$$
\begin{aligned}
& A_{\text {top }} \frac{T_{\text {sub }}-T_{\text {top }}}{r_{\text {top }}}+A_{\text {top }} G_{\text {top }}=A_{\text {top }} G_{\text {top }} \rho_{\text {top }}+A_{\text {top }} \sigma \varepsilon_{\text {top }}\left(T_{\text {top }}^{4}-T_{\text {sky }}^{4}\right)+A_{\text {top }} h_{\text {conv, top }} \\
& \left(\mathrm{T}_{\text {top }}-T_{\mathrm{a}}\right)
\end{aligned}
$$

The fifth energy balance equation is written for the control volume that only includes the parabolic concentrator. In this case, the left side of the energy balance involves the radiation heat transfer between the concentrator and the photovoltaic module as well as the radiation absorbed by the internal surface of the concentrator [6]:

$$
\begin{aligned}
& \mathrm{A}_{\text {pvt }} \sigma \varepsilon_{\text {pvt }}\left(\mathrm{T}_{\text {pvt }}^{4}-\mathrm{T}_{\text {conc }}^{4}\right)+\mathrm{G}_{\text {top }} \mathrm{A}_{\text {conc }} \alpha_{\text {conc }}=\mathrm{A}_{\text {conc }} \sigma \varepsilon_{\text {conc,back }}\left(\mathrm{T}_{\text {conc }}^{4}\right. \\
& \left.\mathrm{T}_{\text {sky }}^{4}\right)+\mathrm{A}_{\text {conc }} \mathrm{h}_{\text {conv,conc,front }}\left(\mathrm{T}_{\text {conc }}-\mathrm{T}_{\mathrm{a}}\right)+\mathrm{A}_{\text {conc }} \mathrm{h}_{\text {conv,conc,back }}\left(\mathrm{T}_{\text {conc }}-\mathrm{T}_{\mathrm{a}}\right)
\end{aligned}
$$

where $\mathrm{A}_{\text {conc }}, \alpha_{\text {conc }}, \varepsilon_{\text {conc,back }}, h_{\text {conv,conc,front }}$ and $h_{\text {conv,conc,back }}$ are the concentrator area, absorptivity of concentrator, emissivity of back surface of concentrator, convective heat transfer coefficient from front surface of concentrator to ambient and convective heat transfer coefficient from back surface of concentrator to ambient, respectively.

Eq. (1), (2), (5), (6) and (7) represent a system of nonlinear equations with five unknown temperatures of $T_{\text {top }}, T_{\text {pvt }}, T_{\text {conc }}, T_{\text {sub }}$ and $T_{\text {out }}$. Due to the presence of the electrical efficiency of the photovoltaic module $\left(\eta_{\mathrm{pv}}\right)$ in Eq. (1), the solution of the mentioned equations is dependent to the calculation of $\eta_{\mathrm{pv}}$. In the previous studies $[6,7$, $12,13]$, the electrical efficiency of the photovoltaic module has been calculated using the following empirical equation: 


$$
\eta_{\mathrm{pv}}=0.298+0.0142 \ln \left(\mathrm{C}_{\mathrm{pvt}}\right)+\left[-0.000715+0.0000697 \ln \left(\mathrm{C}_{\mathrm{pvt}}\right)\right]\left(\mathrm{T}_{\mathrm{pvt}}-298\right)
$$

This equation has a significance error in low solar radiation intensity. In low solar radiation intensity, electrical efficiency should be tend to a low value. However, the empirical equation gives the electrical efficiency equivalent with the electrical efficiency of the reference conditions $\left(T_{\text {pvt,ref }}=293 \mathrm{~K}, \mathrm{G}_{\mathrm{b}, \mathrm{ref}}=1000 \mathrm{~W} / \mathrm{m}^{2}\right)$.

In this study, a comprehensive electrical analysis is performed based on a fourparameter electrical model of current-voltage. This electrical model as follows [14]:

$$
\mathrm{V}=\mathrm{a} \ln \left(\frac{\mathrm{I}_{\mathrm{L}}+\mathrm{I}_{\mathrm{o}}-\mathrm{I}}{\mathrm{I}_{\mathrm{o}}}\right)-\mathrm{IR}_{\mathrm{s}}
$$

where $I$ and $V$ represent the current and voltage of the photovoltaic module. Also, the parameters of $\mathrm{a}, \mathrm{I}_{\mathrm{L}}, \mathrm{I}_{\mathrm{o}}$ and $\mathrm{R}_{\mathrm{S}}$ are ideality factor, light current, diode reverse saturation current and series resistance, respectively. These parameters are calculated from the following equations $[14,15]$.

$$
\begin{aligned}
& \mathrm{a}=\frac{2 \mathrm{~V}_{\mathrm{mp}, \text { ref }}-\mathrm{V}_{\mathrm{oc}, \text { ref }}}{\frac{\mathrm{I}_{\mathrm{mp}, \text { ref }}}{\mathrm{I}_{\mathrm{sc}, \text { ref }} \mathrm{I}_{\mathrm{mp}, \text { ref }}}+\ln \left(1-\frac{\mathrm{I}_{\mathrm{mp}, \mathrm{ref}}}{\mathrm{I}_{\mathrm{sc}, \text { ref }}}\right)}\left(\frac{\mathrm{T}_{\mathrm{pvt}}}{\mathrm{T}_{\mathrm{pvt}, \mathrm{ref}}}\right) \\
& I_{L}=\left(\frac{G_{b}}{G_{b, r e f}}\right)\left[I_{s c, \text { ref }}+\alpha\left(T_{p v t}-T_{\text {pvt,ref }}\right)\right] \\
& I_{0}=\left(\frac{T_{p v t}}{T_{p v t, r e f}}\right)^{3} \exp \left[\frac{\varepsilon N_{c}}{a}\left(\frac{T_{p v t}}{T_{p v t, \text { ref }}}-1\right)\right]\left[I_{s c, \text { ref }} \exp \left(-\frac{V_{o c, r e f} T_{p v t}}{a T_{p v t, r e f}}\right)\right] \\
& \mathrm{R}_{\mathrm{s}}=\mathrm{R}_{\mathrm{s}, \mathrm{ref}}=\frac{\mathrm{a}\left(\frac{\mathrm{T}_{\mathrm{pvt}}}{\mathrm{T}_{\mathrm{pvt} \text {,ref }}}\right) \ln \left(1-\frac{\mathrm{I}_{\mathrm{mp}, \text { ref }}}{\mathrm{I}_{\mathrm{sc} \text {,ref }}}\right)-\mathrm{V}_{\mathrm{mp}, \text { ref }}+\mathrm{V}_{\mathrm{oc}, \text { ref }}}{\mathrm{I}_{\mathrm{mp}, \text { ref }}} \\
& I_{s c}=\left(\frac{G_{b}}{G_{b, r e f}}\right)\left[I_{s c, r e f}+\alpha\left(T_{p v t}-T_{p v t, r e f}\right)\right] \\
& \mathrm{V}_{\mathrm{oc}}=\mathrm{V}_{\mathrm{oc}, \mathrm{ref}}+\beta\left(\mathrm{T}_{\mathrm{pvt}}-\mathrm{T}_{\mathrm{pvt}, \mathrm{ref}}\right)+\mathrm{R}_{\mathrm{s}}\left(\mathrm{I}_{\mathrm{sc}, \mathrm{ref}}-\mathrm{I}_{\mathrm{sc}}\right)
\end{aligned}
$$

where $V_{o c}, I_{s c}, V_{o c, r e f}, V_{m p, r e f}, I_{s c, r e f}, I_{m p, r e f}, \varepsilon, N_{c}, \alpha$ and $\beta$ are open-circuit voltage at actual operating conditions, short-circuit current at actual operating conditions, opencircuit voltage at reference conditions, maximum power point voltage at reference conditions, short-circuit current at reference conditions, maximum power point current at reference conditions, semiconductor band gap energy, solar cells number in series, current temperature coefficient and voltage temperature coefficient, respectively. The value of maximum power point current at actual operating conditions $\left(G_{b}, T_{p v t}\right)$ is obtained from the solution of the following implicit equation $[14,15]$ : 
$a \ln \left(\frac{\mathrm{I}_{\mathrm{L}}+\mathrm{I}_{\mathrm{o}}-\mathrm{I}_{\mathrm{mp}}}{\mathrm{I}_{\mathrm{o}}}\right)-\frac{a \mathrm{I}_{\mathrm{mp}}}{\mathrm{I}_{\mathrm{L}}+\mathrm{I}_{\mathrm{o}}-\mathrm{I}_{\mathrm{mp}}}-2 \mathrm{I}_{\mathrm{mp}} \mathrm{R}_{\mathrm{s}}=0$

Substituting the value of $I_{m p}$ into Eq. (9), the value of maximum power point voltage $\left(\mathrm{V}_{\mathrm{mp}}\right)$ is obtained. Finally, the electrical efficiency of photovoltaic module can be calculated as follows $[14,15]$ :

$$
\eta_{p v}=\frac{V_{m p} I_{m p}}{G_{b} C_{p v t} \eta_{o p t} A_{p v}}
$$

The values of the electrical parameters of photovoltaic module are given in Table 1.

Table 1. Electrical parameters of photovoltaic cells [16]

\begin{tabular}{ll}
\hline Parameter & Value \\
\hline Short circuit current & $\mathrm{I}_{\text {sc,ref }}=4 \mathrm{~A}$ \\
Open circuit voltage & $\mathrm{V}_{\text {oc,ref }}=0.65 \mathrm{~V}$ \\
Series resistance & $\mathrm{R}_{\mathrm{s}, \text { ref }}=0.008 \Omega$ \\
Absorptivity of PV cells & $\alpha_{\text {pvt }}=0.9$ \\
Emissivity of PV cells & $\varepsilon_{\text {pvt }}=0.2$ \\
Semiconductor band gap energy & $\varepsilon=1.79 \mathrm{e}-19 \mathrm{~J} / \mathrm{K}$ \\
Current temperature coefficient & $\alpha=2.06 \mathrm{e}-3 \mathrm{~A} /{ }^{\circ} \mathrm{C}$ \\
Voltage temperature & $\beta=-0.077 \mathrm{~V} /{ }^{\circ} \mathrm{C}$ \\
\hline
\end{tabular}

The output electrical power of the photovoltaic module can be obtained as follows:

$$
\mathrm{P}_{\mathrm{el}}=\mathrm{V}_{\mathrm{mp}} \mathrm{I}_{\mathrm{mp}}
$$

Some of the electrical power generated by the photovoltaic module is used to circulate the agent flow by a pump. The consumed electrical power of the pump can be calculated by the following equation [17]:

$$
\mathrm{P}_{\text {pump }}=\frac{\dot{\mathrm{m}} \Delta \mathrm{p}}{\rho \eta_{\text {pump }}}
$$

In this equation, the parameter of $\eta_{\text {pump }}$ is the pump efficiency. According to Gupta and Kaushik [17], its value is 0.85 . Also, $\Delta \mathrm{p}$ is the fluid pressure loss [18].

$$
\Delta \mathrm{p}=\mathrm{f} \rho_{\mathrm{f}} \frac{\mathrm{L}}{\mathrm{D}} \frac{\overline{\mathrm{V}}^{2}}{2}
$$

Here, the parameters of $f, \bar{V}, \rho_{f}$, L and D represent the Darcy coefficient of friction, the average velocity of the fluid in the pipe, water density, pipe length and pipe diameter. In this study, the flow pipe is considered smooth [18]. Hydraulically smooth means that the roughness on the wall of the pipe is less the thickness of the laminar sub layer of the turbulent flow. A hydraulically smooth pipe has excellent hydraulic properties that allow 
fluids to be flow with a minimum head loss. In the laminar flow, the coefficient of friction is calculated using the Poiseuille equation as follows [18].

$$
\mathrm{f}=\frac{64}{\operatorname{Re}_{\mathrm{f}}}, \quad \mathrm{Re}_{\mathrm{f}} \leq 2300, \text { Laminar flow }
$$

In the turbulent flow, the coefficient of friction is calculated using the Blasius equation as follows [18].

$$
\mathrm{f}=0.3164 \operatorname{Re}_{\mathrm{f}}^{-0.25}, \operatorname{Re}_{\mathrm{f}}>2300 \text {, Turbulent flow }
$$

The net electrical power of the CPVT system is the subtract of consumed electrical power from the electrical power generated by the photovoltaic module as follows.

$$
\mathrm{P}_{\mathrm{el}, \text { net }}=\mathrm{P}_{\mathrm{el}}-\mathrm{P}_{\text {pump }}=\mathrm{V}_{\mathrm{mp}} \mathrm{I}_{\mathrm{mp}}-\mathrm{P}_{\text {pump }}
$$

The overall performance of the CPVT system is evaluated using the thermal and electrical efficiencies based on the beam radiation and the collector aperture area [6]:

$$
\begin{gathered}
\eta_{\mathrm{th}}=\frac{\mathrm{mC}_{\mathrm{f}}\left(\mathrm{T}_{\mathrm{f}, \mathrm{out}}-\mathrm{T}_{\mathrm{f}, \text { in }}\right)}{\mathrm{G}_{\mathrm{b}} \mathrm{A}_{\mathrm{ap}}} \\
\eta_{\mathrm{el}}=\frac{\mathrm{V}_{\mathrm{mp}} \mathrm{I}_{\mathrm{mp}}-\mathrm{P}_{\mathrm{pump}}}{\mathrm{G}_{\mathrm{b}} \mathrm{A}_{\mathrm{ap}}}
\end{gathered}
$$

\section{VALIDATION}

Eq. (1) and (2) and Eq. (5)-(7) consist a set of nonlinear algebraic equations for the unknown temperatures of $\mathrm{T}_{\text {top }}, \mathrm{T}_{\mathrm{pvt}}, \mathrm{T}_{\text {conc }}, \mathrm{T}_{\text {sub }}$ and $\mathrm{T}_{\text {out }}$. This set of equation has been solved by the Newton-Raphson method in MATLAB. The related algorithm as follows Multiple nonlinear equations are:

$$
\mathrm{f}_{\mathrm{i}}\left(\left\{\mathrm{x}_{\mathrm{j}}\right\}\right)=0, \quad 1 \leq \mathrm{i}, \mathrm{j} \leq \mathrm{n}, \quad \text { where } \quad\left\{\mathrm{x}_{\mathrm{j}}\right\}=\left(\mathrm{x}_{1}, \mathrm{x}_{2}, \ldots, \mathrm{x}_{\mathrm{n}}\right)=\mathbf{X}
$$

Write a Taylor expansion in several variables.

$$
\mathrm{f}_{\mathrm{i}}\left(\mathbf{X}^{\mathrm{k}+1}\right)=\mathrm{f}_{\mathrm{i}}\left(\mathbf{X}^{\mathrm{k}}\right)+\left.\sum_{\mathrm{j}=1}^{\mathrm{n}} \frac{\partial \mathrm{f}_{\mathrm{i}}}{\partial \mathrm{x}_{\mathrm{j}}}\right|_{\mathbf{X}^{\mathrm{k}}}\left(\mathrm{x}_{\mathrm{j}}^{\mathrm{k}+1}-\mathrm{x}_{\mathrm{j}}^{\mathrm{k}}\right)+\ldots
$$

The Jacobian matrix is defined as:

$$
\mathrm{J}_{\mathrm{ij}}^{\mathrm{k}}=\left.\frac{\partial \mathrm{f}_{\mathrm{i}}}{\partial \mathrm{x}_{\mathrm{j}}}\right|_{\mathbf{X}^{\mathrm{k}}}
$$

and the Newton-Raphson method is 


$$
\sum_{j=1}^{n} J_{i j}^{k}\left(x_{j}^{k+1}-x_{j}^{k}\right)=-f_{i}\left(X^{k}\right)
$$

Calise and Vanoli analysed the CPVT using TRNSYS [6]. The result for the system temperatures is shown in Fig. 5. To investigate the validity of the research, the numerical simulation of the present study is compared with the numerical analysis done by Calise and Vanoli. The design parameters and boundary conditions of the CPVT during validation process are described in Table 2 and Table 3, respectively. The parameter of $\mathrm{L}_{\text {pvt }}$ is variable in validation analysis.

Table 2. Design parameters of CPVT system [6].

\begin{tabular}{lc}
\hline Parameter & Value \\
\hline Axial length & $\mathrm{L}_{\mathrm{pvt}}=10 \mathrm{~m}$ \\
Aperture width & $\mathrm{L}_{\mathrm{ap}}=1.2 \mathrm{~m}$ \\
Receiver width & $\mathrm{L}_{\mathrm{rec}}=0.06 \mathrm{~m}$ \\
Fluid channel diameter & $\mathrm{D}_{\mathrm{c}}=0.03 \mathrm{~m}$ \\
Fluid specific heat capacity & $\mathrm{C}_{\mathrm{f}}=4187.7 \mathrm{~J} / \mathrm{kg} \mathrm{K}$ \\
Fluid mass flow rate & $\dot{\mathrm{m}}_{\mathrm{f}}=0.15 \mathrm{~kg} / \mathrm{s}$ \\
Top surface absorptivity & $\alpha_{\mathrm{top}}=0.9$ \\
Top surface emissivity & $\varepsilon_{\mathrm{top}}=0.2$ \\
Reflectivity of PV cells & $\rho_{\mathrm{pvt}}=0.03$ \\
Emissivity of PV cells & $\varepsilon_{\mathrm{pvt}}=0.2$ \\
Absorptivity of concentrator & $\alpha_{\text {conc }}=0.03$ \\
Emissivity of back surface of concentrator & $\varepsilon_{\text {conc,back }}=0.3$ \\
\hline
\end{tabular}

Table 3. Boundary conditions of CPVT system [6].

\begin{tabular}{lc}
\hline Variable & Independent variable value \\
\hline Inlet fluid temperature & $\mathrm{T}_{\mathrm{f}, \text { in }}=70{ }^{\circ} \mathrm{C}$ \\
Sky temperature & $\mathrm{T}_{\mathrm{sky}}=25^{\circ} \mathrm{C}$ \\
Ambient temperature & $\mathrm{T}_{\mathrm{a}}=25^{\circ} \mathrm{C}$ \\
Ambient pressure & $\mathrm{P}_{\mathrm{a}}=101 \mathrm{kPa}$ \\
Wind velocity & $\mathrm{W}_{\mathrm{a}}=5 \mathrm{~m} / \mathrm{s}$ \\
Beam radiation & $\mathrm{G}_{\mathrm{b}}=800 \mathrm{~W} / \mathrm{m}^{2}$ \\
Total radiation & $\mathrm{G}_{\mathrm{top}}=1000 \mathrm{~W} / \mathrm{m}^{2}$ \\
\hline
\end{tabular}

As shown in Figure 3, with increased length, all of the temperatures increase. Also, at any given length, the order of the magnitude of the temperatures is the same. Figure 3 shows that the simulation results of this study are consistent with the data of Calise and Vanoli [6]. These results indicate the accuracy of the numerical solution conducted in the present study. The error values given in Table 4 were calculated by means of Eq. (30). In this equation, $n$ is the number of points of comparison for each temperature. 


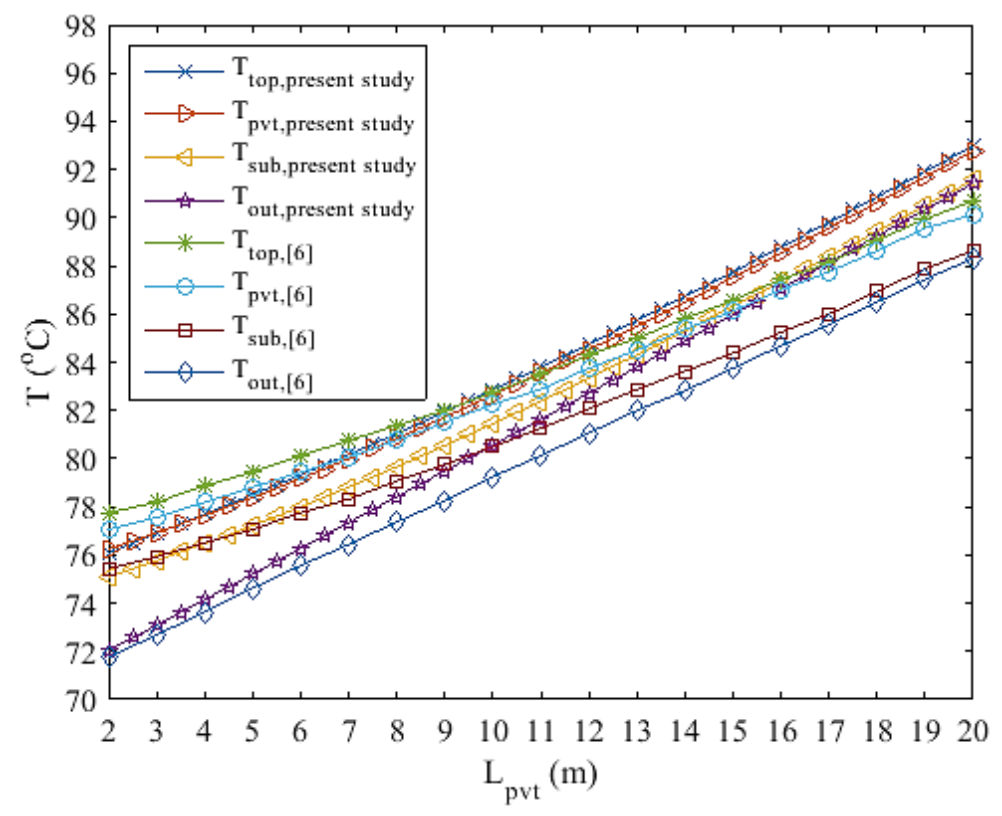

Figure 3. Comparison between the numerical results obtained in the present study and that of Calise and Vanoli [6].

Error $=\frac{1}{n} \sum_{\mathrm{i}=1}^{\mathrm{n}}\left|\frac{\mathrm{T}_{\text {sim, } \mathrm{L}_{\mathrm{pvt}, \mathrm{i}}}-\mathrm{T}_{\text {ref }[6], \mathrm{L}_{\mathrm{pvt}, \mathrm{i}}}}{\mathrm{T}_{\text {ref }[6], \mathrm{L}_{\mathrm{pvt}, \mathrm{i}}}}\right| \times 100$

Table 4. The error values in comparison between the numerical solution results obtained in the present study and that of Calise and Vanoli [6].

\begin{tabular}{lc}
\hline Temperature & Error \\
\hline Top surface temperature of the receiver $\left(\mathrm{T}_{\text {top }}\right)$ & $1.22 \%$ \\
Photovoltaic module temperature $\left(\mathrm{T}_{\mathrm{pvt}}\right)$ & $1.14 \%$ \\
Metallic substrate temperature $\left(\mathrm{T}_{\text {sub }}\right)$ & $1.49 \%$ \\
The fluid temperature at the outlet $\left(\mathrm{T}_{\text {out }}\right)$ & $1.90 \%$ \\
\hline
\end{tabular}

\section{PARAMETRIC STUDIES}

In this section, a parametric study was conducted to analyse the thermal and electrical performance of the CPVT system by changing some design, operational and environmental parameters. The values of the electrical parameters for photovoltaic cells are given in Table 1. Also, these studies were carried out for the parameters presented in Table 2 and Table 3.

\section{Fluid Velocity Effect}

According to Figure 4, with the increase of fluid velocity, the fluid stay time in the flow pipe decreases. Therefore, heat transfer to fluid reduces and as a result, the fluid outlet temperature and other system temperatures are reduced. On the other hand, rising fluid velocity means the increase of the mass flow rate. Therefore, the useful heat gain and the thermal efficiency increases with the increase of mass flow rate (Figure 5). The 
temperature of the photovoltaic module decreases with increasing the fluid velocity. As a result, the cooling of the photovoltaic module increases the electrical power and electrical efficiency (Figure 5). Besides, with the increase of fluid velocity from 0.08 to $0.43 \mathrm{~m} / \mathrm{s}$, the electrical efficiency and thermal efficiency increase by $1.05 \%$ and $2.2 \%$, respectively.

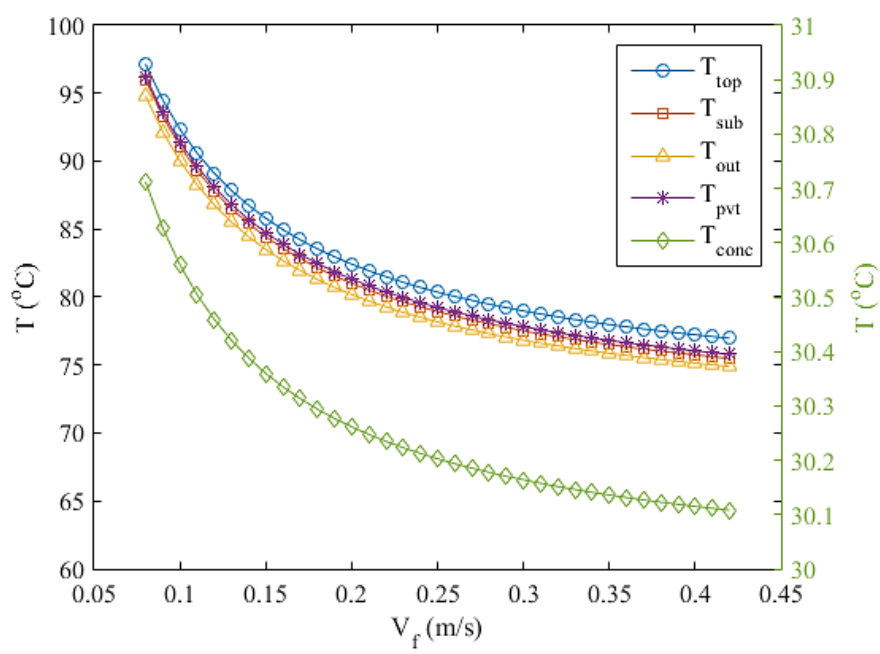

Figure 4. Temperature changes according to the fluid velocity variations.

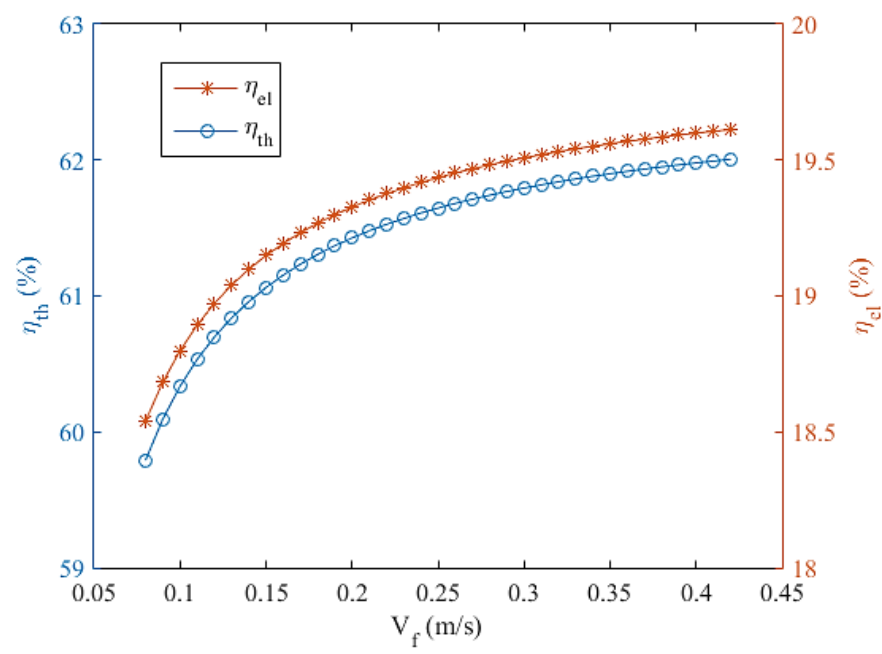

Figure 5. Thermal efficiency and electrical efficiency according to the fluid velocity variations.

\section{Effect of Fluid Channel Diameter}

According to Figure 6, with the increase in the fluid channel diameter, the CPVT system temperatures decrease. The increase of channel diameter causes the increase of the crosssection of the pipe and the mass flow rate. Therefore, the fluid outlet temperature decreases. On the other hand, the increase of mass flow rate due to the increase of the channel diameter increases the thermal efficiency and the electrical efficiency. Increasing the channel diameter at a constant velocity means increasing the heat conduction surface from the substrate to the agent fluid. Therefore, the useful heat gain and the thermal 
efficiency increases with the increase of channel diameter (Figure 7). The temperature of the photovoltaic module decreases with increasing the channel diameter. As a result, the cooling of the photovoltaic module increases the electrical power and electrical efficiency (Figure 7). In addition, with the increase of fluid channel diameter from about 0.017 to $0.06 \mathrm{~m}$, the thermal efficiency and electrical efficiency increase by $2.75 \%$ and $3.9 \%$, respectively.

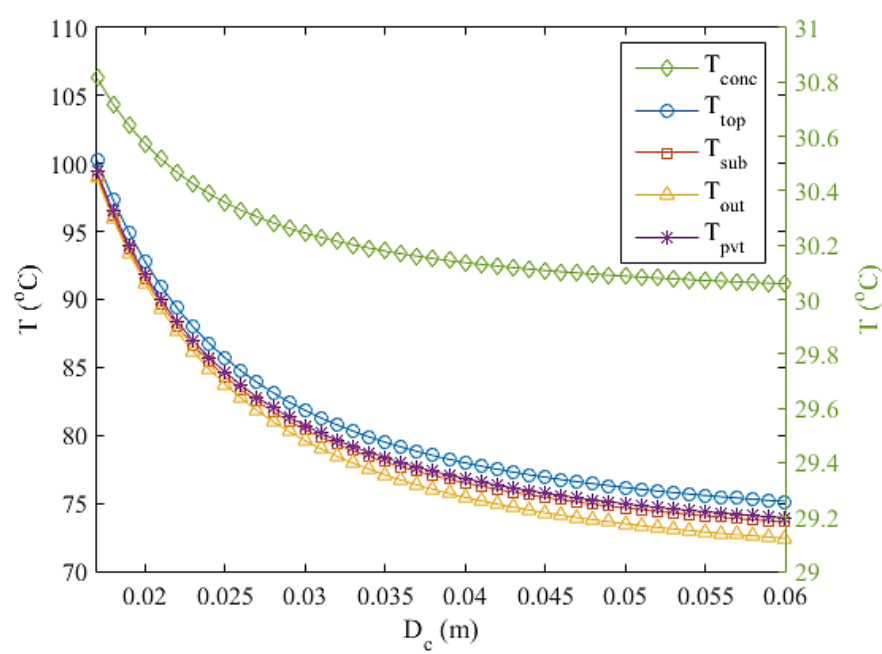

Figure 6. Temperature changes with respect to the diameter of the fluid channel.

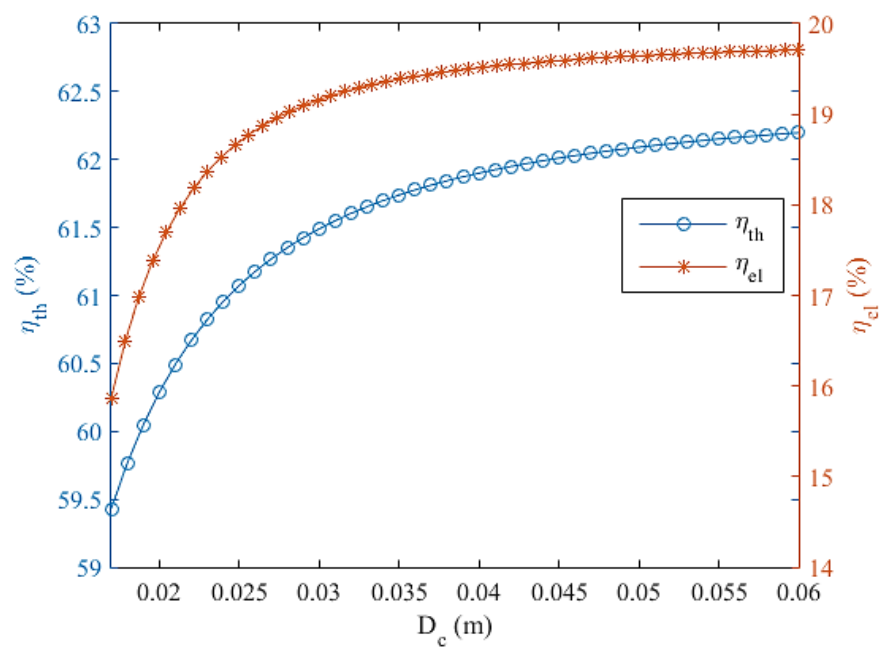

Figure 7. Thermal efficiency and electrical efficiency according to the variations of the fluid channel diameter.

\section{Effect of Axial Length of the CPVT}

The effect of axial length of CPVT system on the CPVT system temperatures and the thermal and electrical efficiencies are shown in Figure 8 and 9, respectively. According to Figure 8, with the increase of axial length, the CPVT system temperatures increases. The original axial length of CPVT system of Calise and Vanoli [6] is $3 \mathrm{~m}$. However, for solar power plant applications, the axial length of CPVT system should be longer. By connecting solar CPVT collectors in series, long lengths can be achieved. The fluid outlet 
temperature of $100{ }^{\circ} \mathrm{C}$, which is suitable for the application of solar power plant, occurs in the lengths of up to $30 \mathrm{~m}$. Although more photovoltaic cells can be used by increasing the length of CPVT system, it can increase the temperature photovoltaic module and the pressure drop. Therefore, the electrical efficiency of CPVT system in the considered range is reduced by $4.4 \%$ (Figure 9 ).

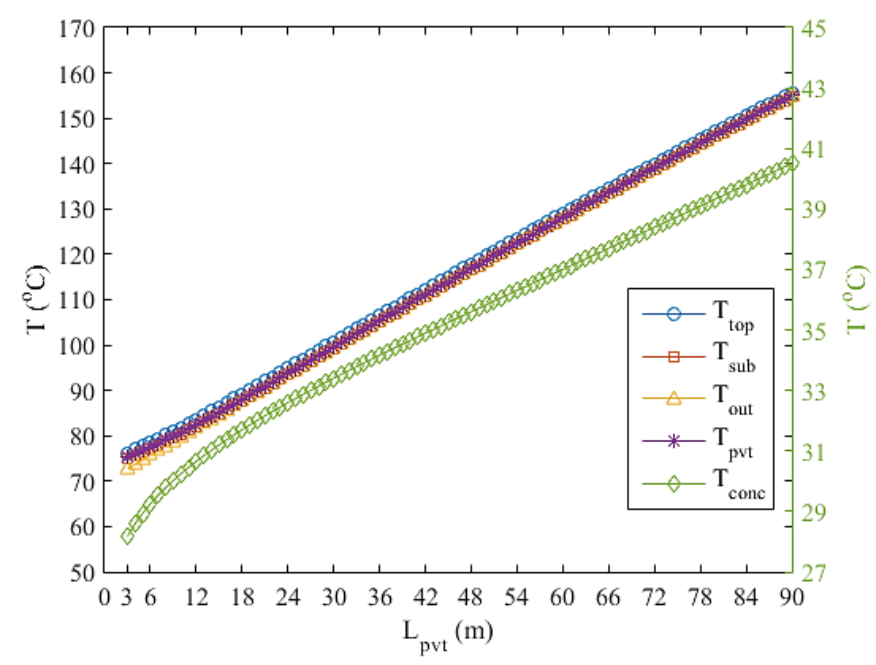

Figure 8 . Temperature variations with respect to the axial length.

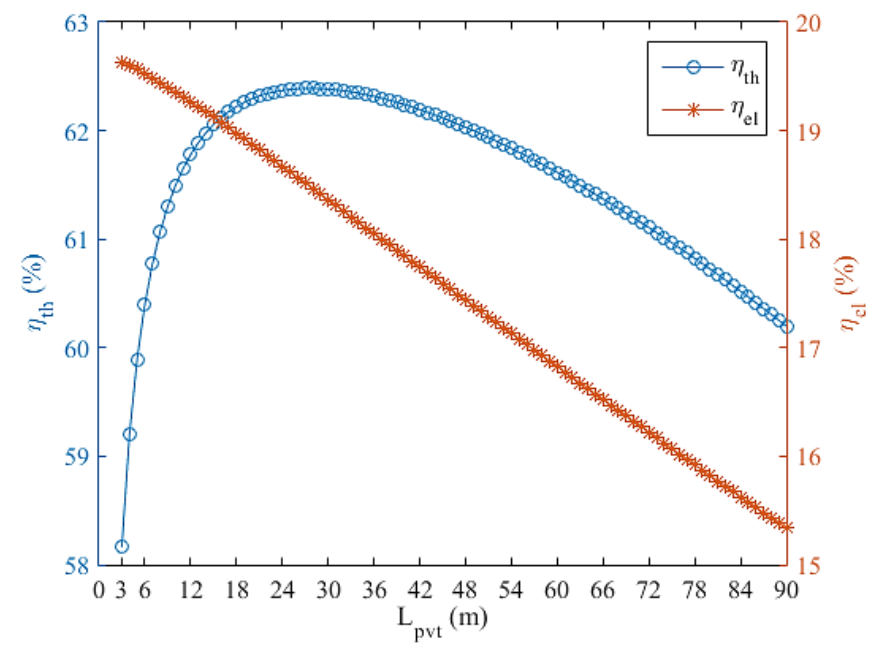

Figure 9. Thermal efficiency and electrical efficiency according to the variations of the axial length

According to Figure 9, with an increase of the axial length of CPVT system to about $30 \mathrm{~m}$, the thermal efficiency increases to about $62.5 \%$. After that, it is reduced to about $60 \%$. The CPVT length of $30 \mathrm{~m}$ can be considered as an optimum length for CPVT system. The increase of axial length of CPVT system after the optimum length of $30 \mathrm{~m}$ increases the collector aperture area so that the heat loss by convection and radiation increases. Therefore, a reduction of $2.4 \%$ in thermal efficiency is seen (Figure 9). 


\section{Effect of Fluid Inlet Temperature}

According to Figure 10, with the increase of the fluid inlet temperature, the CPVT system temperatures increases. Increasing the temperature of the fluid inlet temperature increases the fluid specific heat capacity while reducing its density by increasing the temperature of the fluid inlet temperature, the PV module temperature increases. Therefore, electrical efficiency decreases by about $4.05 \%$ (Figure 11). On the other hand, although the temperature, and consequently the specific heat capacity, of the outlet fluid increase, the increase in the temperature of the inlet fluid is greater than that of the outlet fluid. Therefore, the useful heat gain by CPVT collector will decrease and lead to a reduction of $7.3 \%$ in the thermal efficiency (Figure 11).

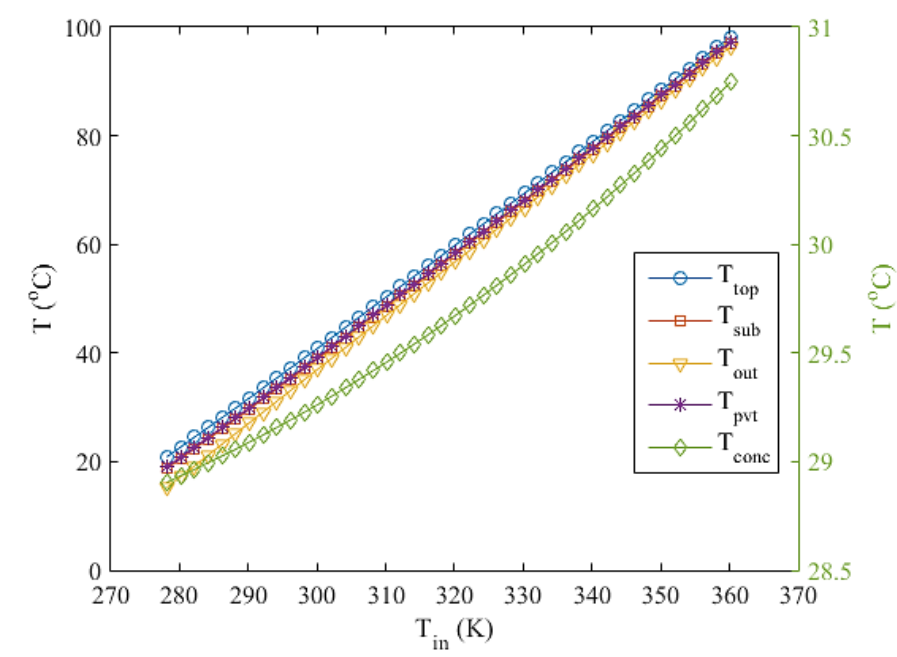

Figure 10. Temperature variations with respect to the fluid inlet temperature.

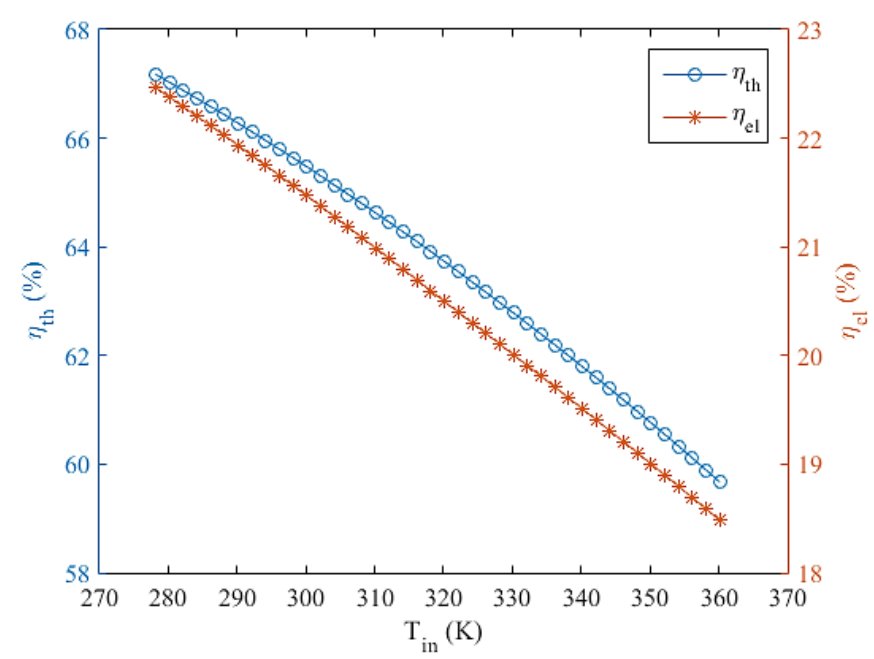

Figure 11. Thermal efficiency and electrical efficiency according to the variations of the fluid inlet temperature. 


\section{Effect of Triangular Receiver Width}

According to Figure 12, with the increase of the width of the receiver, the various temperatures of CPVT system increase. The increase of the width of the receiver causes the increase of absorber surface of the receiver. Therefore, the various temperatures of CPVT system increase. Figure 13 shows that increasing the width of the receiver from 0.06 to $0.2 \mathrm{~m}$ enhances the thermal efficiency by $9.4 \%$. However, its impact on electrical efficiency is negligible. The absorber area, the fluid outlet temperature, and consequently the useful heat gain are increased by increasing the width of the receiver. Therefore, thermal efficiency will increase (Figure 13).

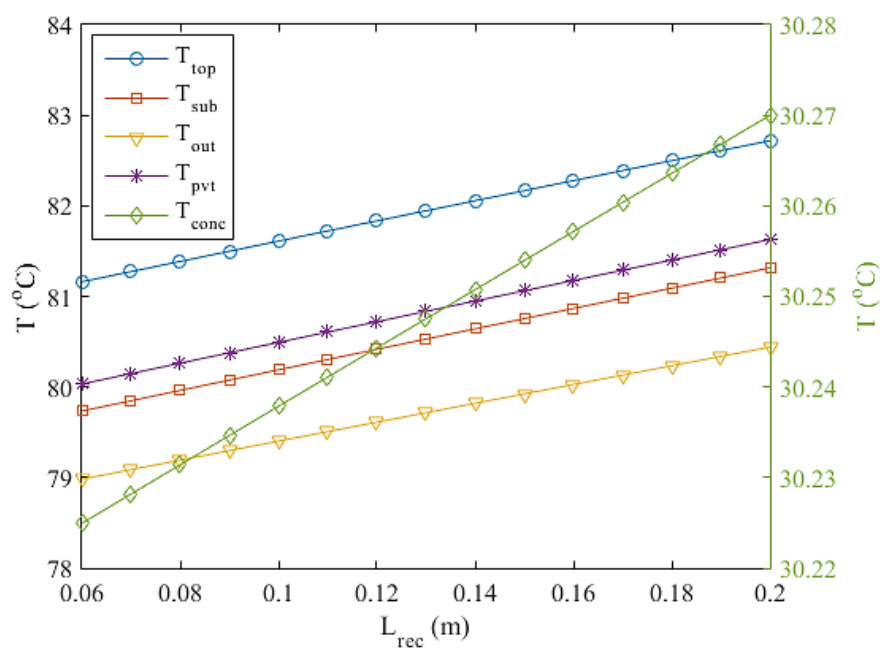

Figure 12. Temperature variations with respect to the width of the receiver.

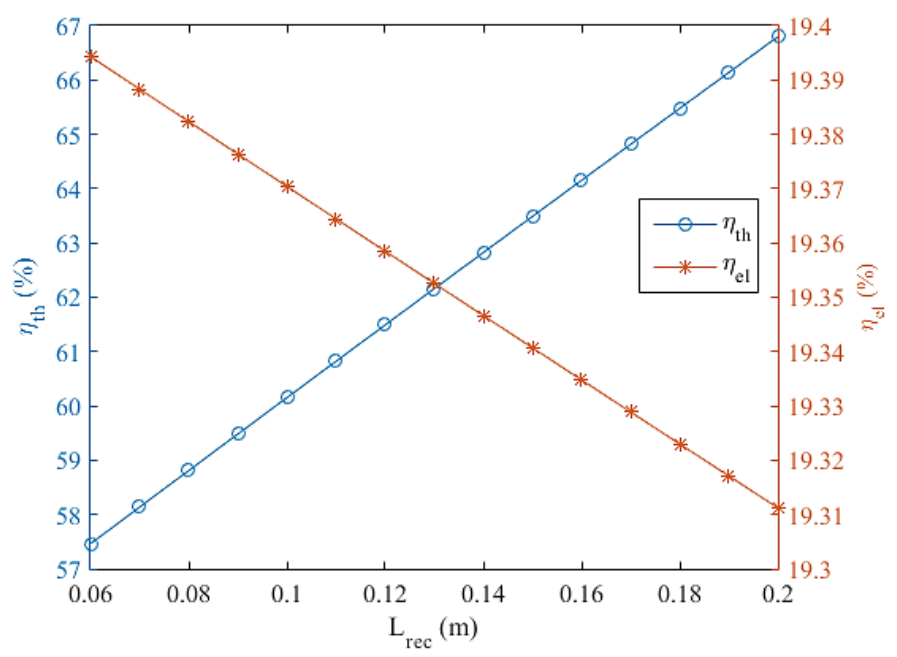

Figure 13. Thermal efficiency and electrical efficiency according to the variations of the width of receiver.

\section{Effect of Solar Radiation}

The effect of solar radiation intensity on the temperatures of CPVT system is shown in Figure 14. According to Figure 14, The CPVT system performance is sensitive to changes 
in solar radiation intensity. Increasing the solar radiation intensity increases the temperatures of the photovoltaic module and the outlet fluid. With the increase of the solar radiation intensity from $300 \mathrm{~W} / \mathrm{m}^{2}$ to $750 \mathrm{~W} / \mathrm{m}^{2}$, the useful heat gain of CPVT system increases. It should be mentioned that the increase in the useful heat gain is more than the increase in the absorbed solar radiation by the CPVT system. Therefore, the thermal efficiency will increase by about $3.75 \%$ (Figure 15).

On the other hand, as the electrical circuit current increases with increasing solar radiation intensity, the photovoltaic module generates more electrical power. Here, the increase in the output electrical power of the photovoltaic module is more than the increase in the absorbed solar radiation by the CPVT system. Therefore, electrical efficiency increases by $4 \%$ (Figure 15).

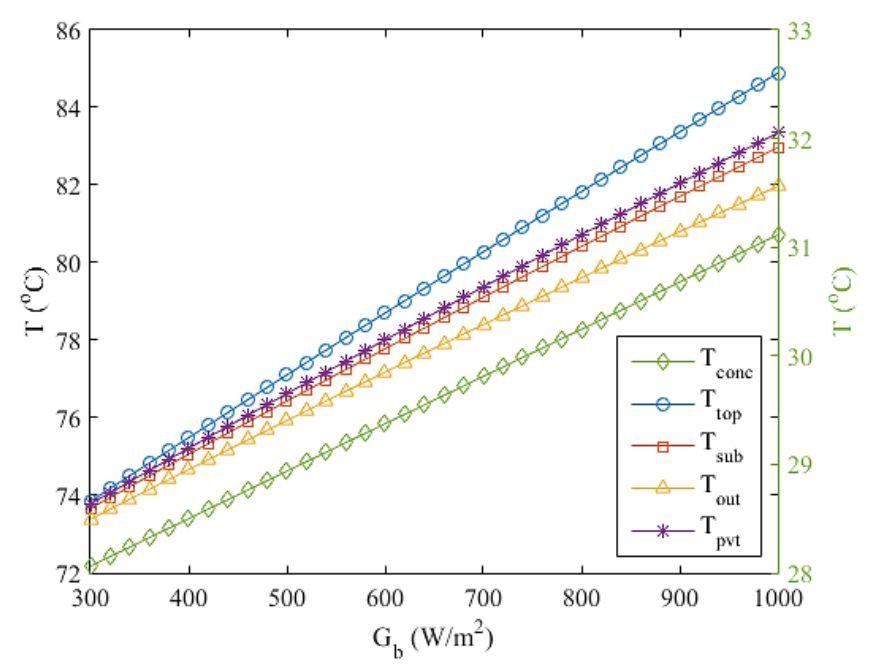

Figure 14. Temperature variations with respect to solar radiation

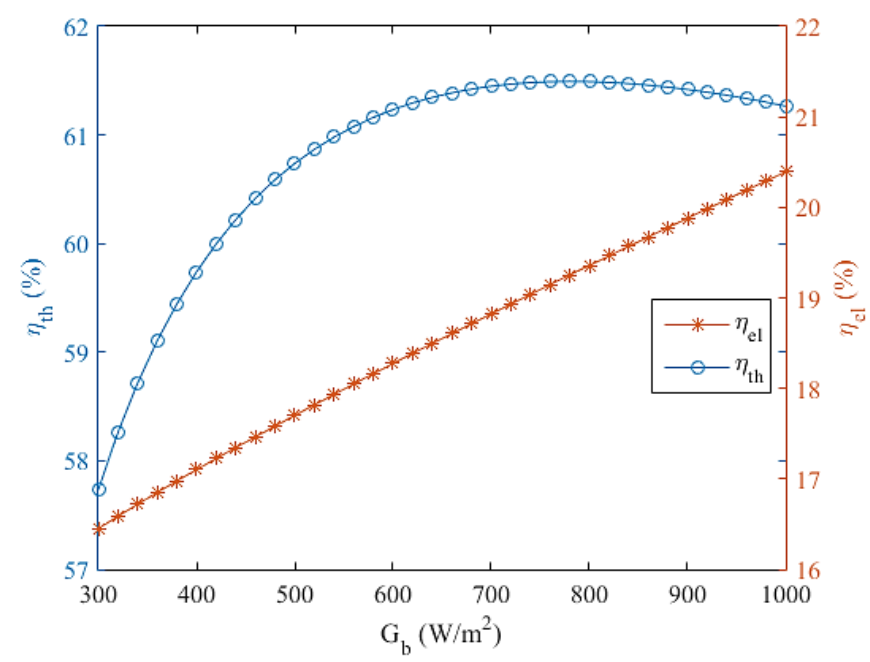

Figure 15. Thermal efficiency and electrical efficiency according to the variations of solar radiation intensity.

A comparison between the electrical efficiency of the present study and the electrical efficiency of Calise and Vanoli [6] has been carried out in Figure 16. According 
to this figure, the electrical efficiency of Calise and Vanoli [6] has a large error in low solar radiation intensity. For this condition, the electrical efficiency should be tend to a low value. However, it tends to the electrical efficiency of the reference conditions.

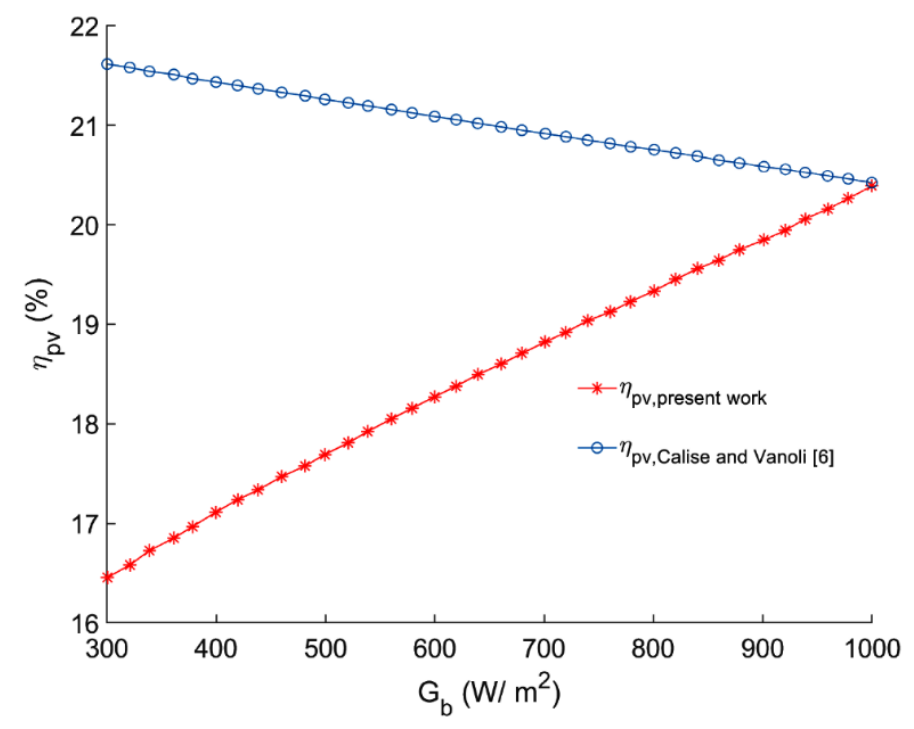

Figure 16. Comparison between the electrical efficiency of the present study and the electrical efficiency of Calise and Vanoli [6].

\section{Effect of Ambient Temperature}

Figure 17 shows the effect of ambient temperature on the various temperatures of the CPVT system. According to this figure, increasing the ambient temperature increases the photovoltaic module temperature and the fluid outlet temperature, in particular, the concentrator temperature. However, the increase in photovoltaic module temperature is less than $1{ }^{\circ} \mathrm{C}$. Therefore, electrical efficiency variations is negligible (Figure 18). On the other hand, the increase of fluid outlet temperature due to the increase of ambient temperature causes the increase of the useful heat gain of CPVT system. Therefore, the thermal efficiency increases by $5.1 \%$ (Figure 18).

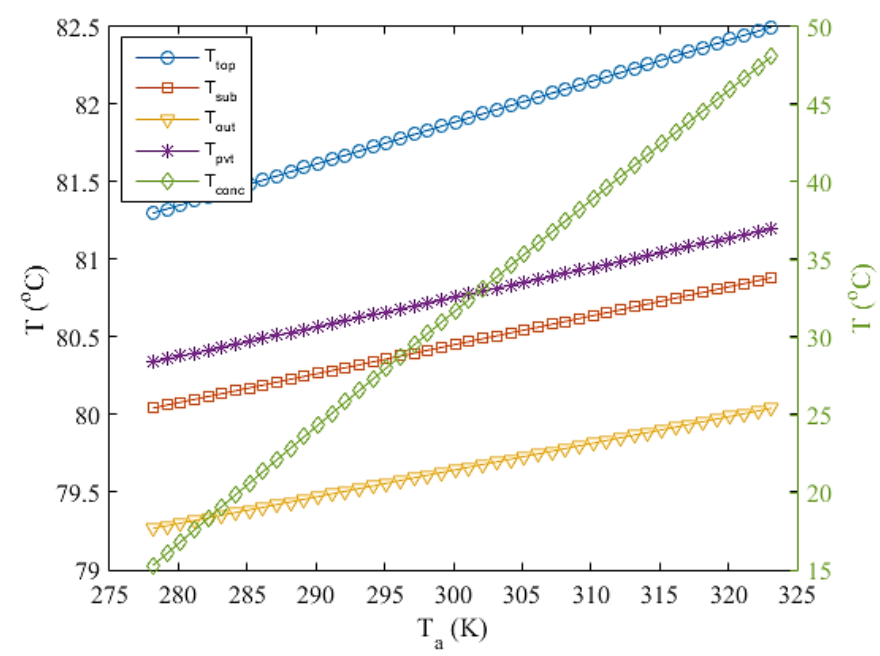

Figure 17. Temperature variations with respect to the ambient temperature. 


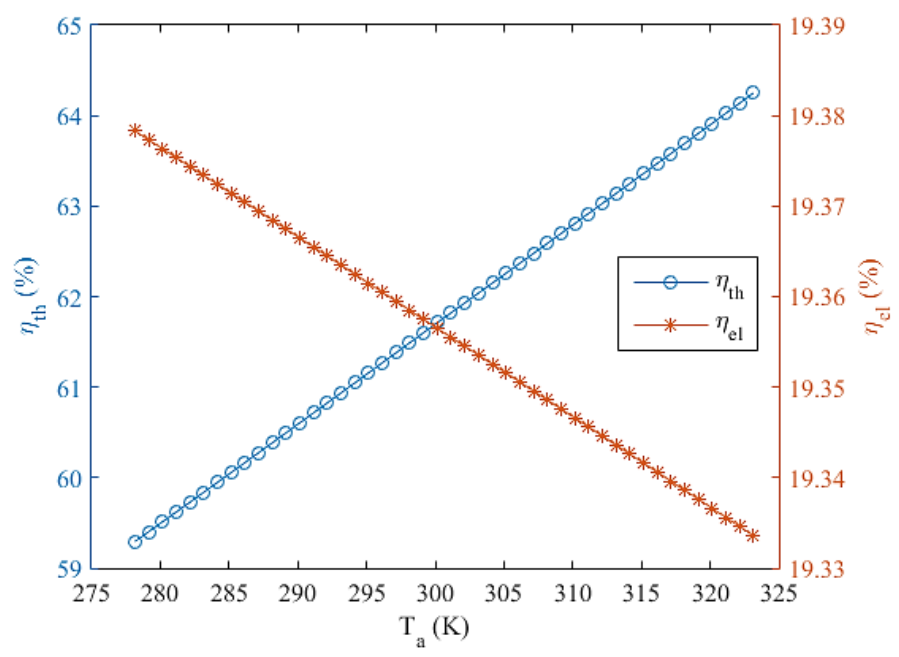

Figure 18. Thermal efficiency and electrical efficiency according to the variations of the ambient temperature.

\section{CONCLUSION}

This study presented the numerical modelling of a concentrating photovoltaic thermal collector (CPVT) collector. In order to obtain the governing equations, the energy balance was written for the various component of the CPVT system. The four-parameter model was used to calculate the electrical efficiency of the photovoltaic module. The results showed that with the increase of fluid velocity from 0.08 to $0.43 \mathrm{~m} / \mathrm{s}$, the electrical efficiency and thermal efficiency was increased by $1.05 \%$ and $2.2 \%$, respectively. The change in the receiver width, which implies a change in the absorber area, was resulted in a $9.4 \%$ increase in the thermal efficiency; while its impact on electrical efficiency was negligible. Increasing the fluid inlet temperature from 273.15 to $363.15 \mathrm{~K}$ reduced the thermal efficiency and electrical efficiency by $7.3 \%$ and $4.05 \%$, respectively. As the collector length increased from 3 to $90 \mathrm{~m}$ the electrical efficiency was reduced by $4.4 \%$ but the thermal efficiency had an ascending/descending trend. With the increase of pipe diameter from 0.017 to $0.06 \mathrm{~m}$, the thermal efficiency and electrical efficiency was increased by $2.75 \%$ and $3.9 \%$, respectively. Although the variation of ambient temperature from 278.15 to $323.15 \mathrm{~K}$ was increased the thermal efficiency by $5.1 \%$, its effect on the electrical efficiency was negligible. With increasing solar radiation intensity from 300 to $1000 \mathrm{~W} / \mathrm{m}^{2}$ the thermal efficiency was changed in an ascending/descending trend and the electrical efficiency was increased by $4 \%$.

\section{REFERENCES}

[1] Zhang X, Zhao X, Smith S, Xu J, Yu X. Review of R\&D progress and practical application of the solar photovoltaic/thermal (PV/T) technologies. Renewable and Sustainable Energy Reviews 2012;16(1):599-617.

[2] Sharaf OZ, Orhan MF. Concentrated photovoltaic thermal (CPVT) solar collector systems: Part I-Fundamentals, design considerations and current technologies. Renewable and Sustainable Energy Reviews 2015;50:1500-65. 
[3] Sharaf OZ, Orhan MF. Concentrated photovoltaic thermal (CPVT) solar collector systems: Part II-Implemented systems, performance assessment, and future directions. Renewable and Sustainable Energy Reviews 2015;50:1566-1633.

[4] Danesh Azarian R, Erdem Cuce E, Mert Cuce, P. 2017. An Overview of concentrating photovoltaic thermal (CPVT) collectors. Energy Research Journal 2017;8(1):11-21.

[5] Bernardo LR, Perers B, Håkansson H, Karlsson B. Performance evaluation of low concentrating photovoltaic/thermal systems: a case study from Sweden. Solar Energy 2011;85(7):1499-510.

[6] Calise F, Vanoli L. Parabolic trough photovoltaic/thermal collectors: design and simulation model. Energies 2012;5(10):4186-208.

[7] Calise F, Palombo A, Vanoli L. A finite-volume model of a parabolic trough photovoltaic/thermal collector: Energetic and exergetic analyses. Energy 2012;46(1):283-94.

[8] Mohsenzadeh M, Shafii MB. A novel concentrating photovoltaic/thermal solar system combined with thermoelectric module in an integrated design. Renewable Energy 2017;113: 822-34.

[9] Sharaf OZ, Orhan MF. Comparative thermodynamic analysis of densely-packed concentrated photovoltaic thermal (CPVT) solar collectors in thermally in-series and in-parallel receiver configurations. Renewable Energy 2018;126: 296-321.

[10] Karathanassis IK, Papanicolaou E, Belessiotis V, Bergeles GC. Dynamic simulation and exergetic optimization of a Concentrating Photovoltaic/Thermal (CPVT) system. Renewable Energy 2019;135: 1035-47.

[11] Kakac S, Liu H. Heat exchanger selection, rating, and thermal design. CRC Press: Boca Raton, FL, USA; 1998.

[12] Calise F, D'Accadia M D, Palombo A, Vanoli L. Dynamic simulation a novel high-temperature solar trigeneration system based on concentrating photovoltaic/thermal collectors. Energy 2013;61:72-86.

[13] Mittelman G, Kribus A, Dayan A. Solar cooling with concentrating photovoltaic/thermal (CPVT) systems. Energy Conversion and Management 2007;48:2481-90.

[14] Townsend TU. Simplified performance modelling of direct-coupled photovoltaic systems, M.S. Thesis, Department of Mechanical Engineering, University of Wisconsin-Madison, USA; Chapter 2, pp. 17-110, 1989.

[15] De Soto W. Improvement and validation of a model for photovoltaic array performance. M.S. Thesis, Solar Energy Laboratory, University of WisconsinMadison, USA; 2004.

[16] Bernardo R. Retrofitted solar domestic hot water system for single-family electrically-heated houses, Doctoral Dissertation, Department of Architecture and Built Environment, Division of Energy and Building Design, Lund University, Sweden; 2010.

[17] Gupta MK, Kaushik SC. Exergetic performance evaluation and parametric studies of solar air heater. Energy 2008;33:1691-1702.

[18] White FM. Fluid mechanics. 4th ed. McGraw-Hill, Co; 2003. 